\title{
Identification of a common enterobacterial flagellin epitope with a monoclonal antibody
}

\author{
Peter Feng, $\uparrow$ Renee J. Sugasawara* and Allen Schantz
}

IGEN Inc., 1530 East Jefferson Street, Rockville, MD 20852, USA

(Received 11 September 1989; revised 8 November 1989; accepted 13 November 1989)

\begin{abstract}
A monoclonal antibody (mAb), designated 15D8, was produced from BALB/c splenocytes of mice injected with Escherichia coli flagella. ELISA of motile cells, non-motile cells and partially purified fiagellin proteins showed that the $\mathrm{mAb}$ reacted specifically with flagella of $E$. coli and with other members of the family Enterobacteriaceae. Western immunoblot analyses of enterobacterial flagella or cell extracts demonstrated that the antibody reacted with a single protein species in the extracts which was identical in size to purified flagellin. The antigenic determinant for this antibody appears to be surface exposed and linear in configuration, since the antibody reacted with native flagella and flagella which had been denatured. This antibody was also used to demonstrate that although the flagella proteins are heterogeneous in size, at least one epitope is highly conserved.
\end{abstract}

\section{Introduction}

The flagellar filament is a unique structure and is the major component of bacterial flagella (Joys, 1988; Macnab, 1987). Unlike the eukaryotic flagellum, which is relatively large and contains many proteins, the bacterial filament is much smaller in size and composed of several thousand copies of a monomeric protein, flagellin (Iino, 1977; Macnab, 1987). The $M_{\mathrm{r}}$ of flagellin varies greatly amongst bacteria, ranging from 28000 in some Bacillus species to over 60000 for some members of the family Enterobacteriaceae (Ibrahim et al., 1985a; Joys, 1988; Kondoh \& Hotani, 1974; Kuwajima et al., 1986; Lawn, 1977; McDonough \& Smith, 1976). Despite this variation in $M_{\mathrm{r}}$, nucleic acid and peptide analyses of flagellin from many genera show considerable homology and sequence conservation (Homma et al., 1987; Joys, 1985; Kuwajima, 1988 a, $b$; Szekely \& Simon, 1983; Wei \& Joys, 1985).

Serological studies on flagella are important clinically for classification and identification of bacteria. For instance, the epitope for the IgA monoclonal antibody (mAb) MOPC467 is highly conserved in Salmonella species. This antibody reacts with most of the 1800

$\uparrow$ Present Address: Food and Drug Administration, Division of Microbiology, Washington, DC 20204, USA.

Abbreviation: mAb, monoclonal antibody. serotypes of Salmonella (Smith \& Potter, 1976), including both phase I and phase II flagellar types (Smith \& Jones, 1983). Most other closely related and flagellated bacteria in the family Enterobacteriaceae do not react with the antibody (Robison et al., 1983), so that MOPC467 is useful for the identification of Salmonella species.

Both the flagellar filament and the monomeric flagellin protein are potent immunogens. However, not all antigenic epitopes present on native flagella are present on the monomeric proteins (Ibrahim et al., $1985 c$; Joys, 1988). Serological studies of enterobacterial flagellin have revealed the presence of numerous major and minor antigenic components, including conformational and linear epitopes, which display varying degrees of conservation (Ada et al., 1964; Langman, 1972). Ibrahim et al. (1985b) used native Salmonella flagella to produce polyclonal antisera which were specific for Salmonella serotypes. However, the same antisera were broadly reactive with all Salmonella serotypes and other enterobacterial flagella if the flagellar filaments were denatured prior to testing. Unfortunately, it is unclear whether the same antibodies are responsible for both reactivities.

To elucidate whether the structurally conserved flagellar region is also antigenically conserved, we prepared mAbs against Escherichia coli flagella. The antibodies were tested for reactivity with different genera from the family Enterobacteriaceae to determine whether the flagella of these organisms are related 
antigenically. We also wanted to determine whether the conserved epitope could be found on intact flagella or whether the flagella require denaturation to expose the primary amino acid sequence.

\section{Methods}

Bacterial strains. The organisms used in this study are listed in Table 1. They included 109 Escherichia coli strains from clinical and animal sources, and from food and water, six clinical isolates of various Salmonella species, and 140 Enterobacteriaceae and 20 Pseudomonaceae that were isolated from water samples collected from the eastern and midwestern sections of the United States. The isolates were identified using the Micro-ID (Organon Teknika) or the API20E

Table 1. Source of bacteria

\begin{tabular}{|c|c|c|c|}
\hline Bacterium & Strain & Source & Reference* \\
\hline Citrobacter freundii & 33128 & Clinical & ATCC \\
\hline $\begin{array}{l}\text { Edwardsiella tarda } \\
\text { Edwardsiella tarda }\end{array}$ & $\begin{array}{l}15947 \\
\text { CW4 }\end{array}$ & $\begin{array}{l}\text { Clinical } \\
\text { Water }\end{array}$ & $\begin{array}{l}\text { ATCC } \\
\text { Environmental }\end{array}$ \\
\hline $\begin{array}{l}\text { Enterobacter aerogenes } \\
\text { Enterobacter aerogenes } \\
\text { Enterobacter agglomerans } \\
\text { Enterobacter cloacae } \\
\text { Enterobacter cloacae } \\
\text { Enterobacter gergovia }\end{array}$ & $\begin{array}{l}13048 \\
\text { Assorted } \\
\text { Assorted } \\
13047 \\
\text { Assorted } \\
\text { Assorted }\end{array}$ & $\begin{array}{l}\text { Clinical } \\
\text { Water } \\
\text { Water } \\
\text { Clinical } \\
\text { Water } \\
\text { Water }\end{array}$ & $\begin{array}{l}\text { ATCC } \\
\text { Environmental } \\
\text { Environmental } \\
\text { ATCC } \\
\text { Environmental } \\
\text { Environmental }\end{array}$ \\
\hline $\begin{array}{l}\text { Escherichia coli } \\
\text { Escherichia coli }\end{array}$ & $\begin{array}{l}\text { EC1-72 } \\
1-37\end{array}$ & \multicolumn{2}{|c|}{$\begin{array}{lc}\text { See O \& S } \\
\text { Food, } & \mathrm{H} \\
\text { Water } & \end{array}$} \\
\hline Escherichia coli & Assorted & Water & Environmental \\
\hline Hafnia alvei & Assorted & Water & Environmental \\
\hline $\begin{array}{l}\text { Klebsiella oxytoca } \\
\text { Klebsiella pneumoniae } \\
\text { Klebsiella pneumoniae }\end{array}$ & $\begin{array}{l}\text { Assorted } \\
23357 \\
\text { Assorted }\end{array}$ & $\begin{array}{c}\text { Water } \\
- \\
\text { Water }\end{array}$ & $\begin{array}{l}\text { Environmental } \\
\text { ATCC } \\
\text { Environmental }\end{array}$ \\
\hline $\begin{array}{l}\text { Proteus mirabilis } \\
\text { Proteus mirabilis } \\
\text { Proteus vulgaris }\end{array}$ & $\begin{array}{l}25933 \\
\text { Assorted } \\
13315\end{array}$ & $\begin{array}{c}\text { Clinical } \\
\text { Water } \\
-\end{array}$ & $\begin{array}{l}\text { ATCC } \\
\text { Environmental } \\
\text { ATCC }\end{array}$ \\
\hline $\begin{array}{l}\text { Pseudomonas aeruginosa } \\
\text { Pseudomonas fluorescens } \\
\text { Pseudomonas } \text { spp. }\end{array}$ & $\begin{array}{l}14207 \\
13525 \\
\text { Assorted }\end{array}$ & $\begin{array}{l}\text { Clinical } \\
\text { Water } \\
\text { Water }\end{array}$ & $\begin{array}{l}\text { ATCC } \\
\text { ATCC } \\
\text { Environmental }\end{array}$ \\
\hline $\begin{array}{l}\text { Salmonella arizonae } \\
\text { Salmonella gallinarum } \\
\text { Salmonella paratyphi B } \\
\text { Salmonella tennessee } \\
\text { Salmonella typhi } \\
\text { Salmonella typhimurium } \\
\text { Salmonella worthington }\end{array}$ & O8 & $\begin{array}{l}\text { Water } \\
\text { Clinical } \\
\text { Clinical } \\
\text { Clinical } \\
\text { Clinical } \\
\text { Clinical } \\
\text { Clinical }\end{array}$ & $\begin{array}{l}\text { Environmental } \\
\text { S } \\
\text { S } \\
\text { S } \\
\text { S } \\
\text { S } \\
\text { S }\end{array}$ \\
\hline $\begin{array}{l}\text { Serratia liquefaciens } \\
\text { Serratia marcescens } \\
\text { Serratia marcescens } \\
\text { Serratia rubidea }\end{array}$ & $\begin{array}{l}\text { Assorted } \\
8100 \\
\text { Assorted } \\
\text { Assorted }\end{array}$ & $\begin{array}{l}\text { Water } \\
- \\
\text { Water } \\
\text { Water }\end{array}$ & $\begin{array}{l}\text { Environmental } \\
\text { ATCC } \\
\text { Environmental } \\
\text { Environmental }\end{array}$ \\
\hline $\begin{array}{l}\text { Shigella sonnei } \\
\text { Shigella sp. }\end{array}$ & $\begin{array}{l}9290 \\
\text { Assorted }\end{array}$ & Water & $\begin{array}{l}\text { ATCC } \\
\text { Environmental }\end{array}$ \\
\hline $\begin{array}{l}\text { Yersinia enterocolitica } \\
\text { Yersinia enterocolitica }\end{array}$ & $\begin{array}{l}\mathrm{MC} 23 \\
\mathrm{O} 8\end{array}$ & Water & Environmental \\
\hline
\end{tabular}

${ }^{*}$ ATCC, American Type Culture Collection, Rockville, MD, USA; H, P. A. Hartman, Iowa State University, Ames, IA, USA; O \& S, H. Ochman \& R. K. Selander (1984) (University of Rochester, Rochester, NY, USA); S, B. Swaminathan, Purdue University, W. Lafayette, IN, USA. system (API Analytab Products). All media used were commercial products and prepared according to the manufacturer's specifications.

Flagellin isolation. Motile isolates of bacteria were obtained by two passages on brain heart infusion $(\mathrm{BHI}) / 0.4 \%$ agar plates at $35^{\circ} \mathrm{C}$. Motility was confirmed by microscopic examination of sample wet mounts. Motile cells induced from non-motile isolates were collected after three passages through U-tubes containing BHI medium plus $0.4 \%$ agar.

Bacterial flagellin was isolated using a procedure obtained from $P$ Matsumura, University of Illinois, USA. Briefly, motile cells were grown overnight in nutrient broth containing $0.5 \% \mathrm{NaCl}$ and then harvested by centrifugation. The cell pellet was resuspended in phosphate-buffered saline (PBS; $10 \mathrm{~mm}$-sodium phosphate, $150 \mathrm{~mm}$ -

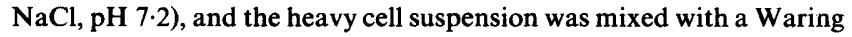
blender for $1 \mathrm{~min}$ to shear the flagellar filaments. After removing the bacterial cells by low-speed centrifugation, the supernatant fluid was centrifuged at $77000 \mathrm{~g}$ for $3 \mathrm{~h}$ (Beckman SW41-Ti swinging bucket rotor) to pellet the flagellar protein. The pellet of partially purified flagellin protein was resuspended in PBS overnight and then stored at $-20^{\circ} \mathrm{C}$.

$m A b$ production and analyses. Anti-flagellin $\mathrm{mAbs}$ were produced using standard methods previously described (Sugasawara et al., 1983). Briefly, flagellin proteins from E. coli strains EC8 and EC51 were injected into 8-week-old BALB/c mice as an emulsion of $10 \mu \mathrm{g}$ of proteins in Freund's complete adjuvant. The mice were boosted 11 and 40 days later with an additional $10 \mu \mathrm{g}$ of the same flagellin protein in Freund's incomplete adjuvant; $3 \mathrm{~d}$ after the final boost, spleen cells were prepared for fusion with SP2/O myeloma cells.

The mAbs obtained were screened by ELISA using Immulon II Microtiter plates. The plate wells were coated overnight at $4{ }^{\circ} \mathrm{C}$ with $50 \mu \mathrm{l}$ of antigen, which consisted of either flagellin protein at a concentration of $2 \mu \mathrm{g} \mathrm{ml}^{-1}$ in $50 \mathrm{mM}$-sodium carbonate buffer, $\mathrm{pH} \mathrm{9.5}$, or a bacterial cell suspension prepared to an $\mathrm{OD}_{550}$ of 0.20 in $50 \mathrm{mM}$ carbonate buffer. After antigen coating, the wells were washed with PBS, and blocked with $200 \mu \mathrm{l}$ of $3 \%$ (w/v) BSA/PBS. The blocking step and all subsequent incubations were for $1 \mathrm{~h}$ at $35^{\circ} \mathrm{C}$. Following BSA blocking, $50 \mu \mathrm{l}$ of hybridoma supernatant fluids or appropriate dilutions of mouse ascites fluids in $1 \%(\mathrm{w} / \mathrm{v})$ BSA/PBS were added to the wells. The negative control mAb MCAl4.2 was prepared against Neisseria meningitidis lipopolysaccharide (Sugasawara et al., 1983). To detect the antigen-antibody complexes, the wells were treated with $50 \mu \mathrm{l}$ of peroxidase-conjugated goat anti-mouse IgG used at a $1: 1000$ dilution in $1 \%(w / v)$ BSA/PBS. After each step, unbound reagents in the wells were removed by repeated washing with PBS containing $0.05 \%$ Tween 20 . The peroxidase enzyme substrate, 2,2 '-azino-di(3ethylbenzylthiazoline sulphonate), was used at a volume of $100 \mu \mathrm{l}$ per well; after $30 \mathrm{~min}$ at room temperature the absorbance was determined using a Titertek Multiskan reader with a $414 \mathrm{~nm}$ filter.

Isotypes of the mAbs were determined by ELISA using an antibody isotyping kit (Zymed).

Gel electrophoresis. Electrophoresis of flagellin proteins was done in SDS-polyacrylamide gels in the Tris/glycine discontinuous buffer system (Laemmli, 1970). A 3\% (w/v) acrylamide stacking gel was used with a $10 \%(\mathrm{w} / \mathrm{v})$ acrylamide separating gel. Approximately 5 to $10 \mu \mathrm{g}$ of each partially purified flagellin preparation in $20 \mu \mathrm{l}$ of sample buffer $(0 \cdot 12 \mathrm{M}$-Tris/HCl, $\mathrm{pH} 6.8 ; 5 \%, \mathrm{w} / \mathrm{v}, \mathrm{SDS} ; 2 \%, \mathrm{v} / \mathrm{v}, 2$-mercaptoethanol; $25 \%$, v/v, glycerol; and $0.25 \%$ bromphenol blue dye) was boiled for 15 min then loaded into the gel lane. Protein $M_{\mathrm{r}}$ markers (Bio-Rad) were treated similarly. Following electrophoresis, gels were stained for $18 \mathrm{~h}$ with $0.025 \%$ Coomassie brilliant blue G-250 in $25 \%$ (v/v) 2propanol $/ 10 \%(\mathrm{v} / \mathrm{v})$ acetic acid, destained for $24 \mathrm{~h}$ with $0.0025 \%$ Coomassie blue in $10 \%(\mathrm{v} / \mathrm{v})$ 2-propanol $/ 10 \%$ (v/v) acetic acid, and then stored in $10 \%(\mathrm{v} / \mathrm{v})$ acetic acid solution. 
Immunobloting. Proteins fractionated on SDS-polyacrylamide gels were electrophoretically transferred onto nitrocellulose papers. The transfer was done in Tris/glycine/methanol buffer $(25 \mathrm{mM}-\mathrm{Tris} / \mathrm{HCl}$, pH $8.3 ; 192 \mathrm{~mm}$-glycine; $20 \%, \mathrm{v} / \mathrm{v}$, methanol) at $0.6 \mathrm{~A}$ for $2 \mathrm{~h}$ with a LKB 2005 Transphor unit. To assay for the presence of specific proteins, the nitrocellulose membranes were first treated overnight with $3 \%(w / v)$ BSA/PBS to reduce non-specific binding. Next, hybridoma supernatant or ascites fluids diluted in $1 \%(w / v)$ BSA/PBS were incubated with the blots for $2 \mathrm{~h}$ at $35^{\circ} \mathrm{C}$ to allow antibody to bind to specific proteins. To detect the antigen-antibody complexes, horseradish peroxidase conjugated to goat anti-mouse $\mathrm{IgG}$ was diluted $1: 1000$ in $1 \%(w / v)$ BSA/PBS and incubated with the blots for $2 \mathrm{~h}$ at $35^{\circ} \mathrm{C}$. Following each step, unbound reagents were removed by four washes, each $15 \mathrm{~min}$, with PBS containing $0 \cdot 1 \%$ Triton X-100. The blots were finally treated for $30 \mathrm{~min}$ at room temperature with a precipitable substrate solution consisting of 0.02\% 4-chloro-1-naphthol, $10 \%$ (viv) methanol and $0.01 \%$ hydrogen peroxide in PBS. The developed blots were rinsed with PBS and dried at room temperature.

\section{Results}

\section{Preparation of anti-flagella $m A b s$}

Flagellar protein from two $E$. coli strains was used for the production of hybridomas. Of the 2318 colonies obtained and assayed for antibody by ELISA, 227 produced antibody against $E$. coli EC8 and/or EC51 flagella preparations. Seventy-three hybridomas remained stable producers of antibody after another $10 \mathrm{~d}$, and six were selected for cloning by limiting dilution. The antibodies from the clones showed strong reactivity to the $E$. coli flagellar antigens without cross-reactivity to the non-enteric bacteria (Pseudomonas strains), and were produced as ascites fluids.

\section{Antibody specificity}

Five of the six antibodies were examined by ELISA for reactivity with natural isolates from food and water, and the clinical and laboratory isolates. Two of the mAbs were highly specific, reacting with only five strains of $E$. coli. Two were intermediate in reactivity, reacting with approximately 40 to $60 \mathrm{E}$. coli isolates and a few Enterobacter and Serratia. One antibody designated $15 \mathrm{D} 8\left(\mathrm{IgG}_{1}, \kappa\right)$ showed cross-reactivity with the majority of genera in the Enterobacteriaceae with the exception of Klebsiella and Shigella (Table 2).

To determine whether the cross-reactions of $\mathrm{mAb}$ 15D8 with the other genera of Enterobacteriaceae were due to binding to flagella or another component of the organism, crude cell lysates and purified flagella were fractionated by SDS-PAGE. Total cellular extracts of Enterobacter, Salmonella, Hafnia and Serratia yielded only a single protein which reacted with $\mathrm{mAb}$ 15D8 by immunoblotting (Fig. 1). Similarly, E. coli lysates yielded only one reactive protein (data not shown). In each case,

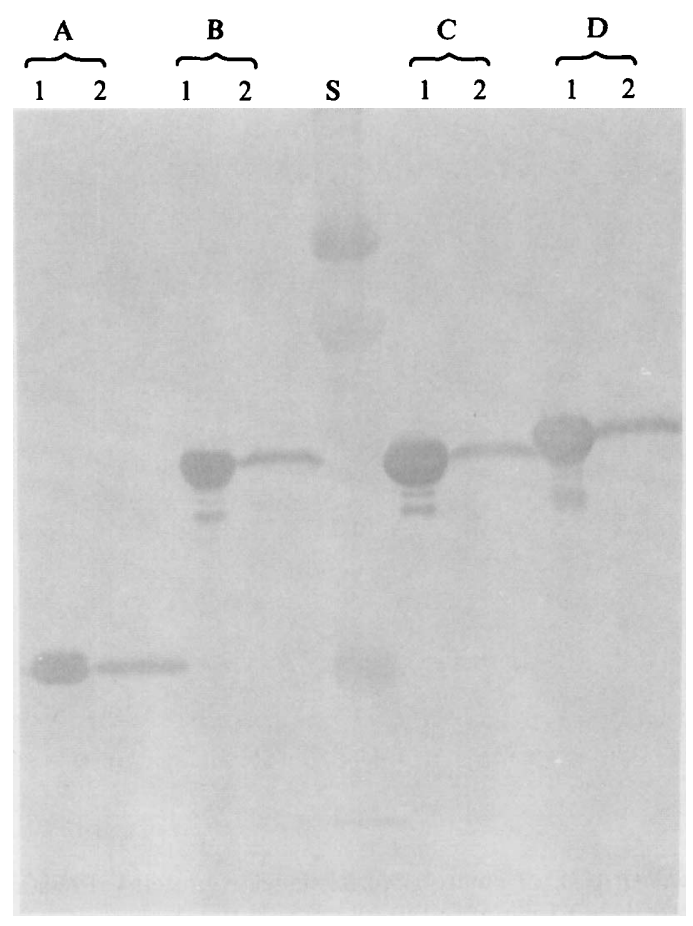

Fig. 1. Western immunoblot of flagellin and cell extracts of bacterial isolates using mAb 15D8. The samples were: Enterobacter cloacae NJ4 (A); Salmonella arizonae O8 (B); Hafnia alvei W12 (C); and Serratia rubidea $\mathrm{O} 10$ (D). For each isolate, flagellin protein was loaded in lane 1, and total crude cell extracts in lane 2. $M_{\mathrm{r}}$ markers (lane $\mathrm{S}$ ) comprised (from top to bottom): phosphorylase B $\left(M_{\mathrm{r}} 97000\right)$; BSA (65000); ovalbumin (45000); carbonic anhydrase (31000); and trypsin inhibitor (20000).

Table 2. ELISA of mAb 15D8 on environmental, clinical and laboratory isolates

Fresh cultures of each of the isolates were prepared as a suspension of whole bacteria and used to coat ELISA plates. Isolates showing twofold or greater $A_{414}$ readings with 15D8 as compared to the negative control antibody MCA14.2 were considered positive.

\begin{tabular}{lcc}
\hline \multicolumn{1}{c}{ Bacteria } & $\begin{array}{c}\text { Number } \\
\text { tested }\end{array}$ & $\begin{array}{c}\text { Number } \\
\text { positive }\end{array}$ \\
\hline Citrobacter freundii & 1 & 1 \\
Edwardsiella tarda & 2 & 2 \\
Enterobacter spp. & 33 & 14 \\
Escherichia coli & 165 & 99 \\
Hafnia spp. & 6 & 1 \\
Proteus spp. & 8 & 7 \\
Salmonella spp. & 7 & 7 \\
Serratia spp. & 12 & 9 \\
Yersinia enterocolitica & 2 & 2 \\
Klebsiella spp. & 19 & 0 \\
Pseudomonas spp. & 22 & 0 \\
Shigella spp. & 4 & 0 \\
\hline \hline
\end{tabular}

the antibody-reactive protein species was identical in size to the flagellin protein isolated for each strain. No antibody-reactive protein species were detected in the immunoblot analyses of cell lysates from Shigella, 


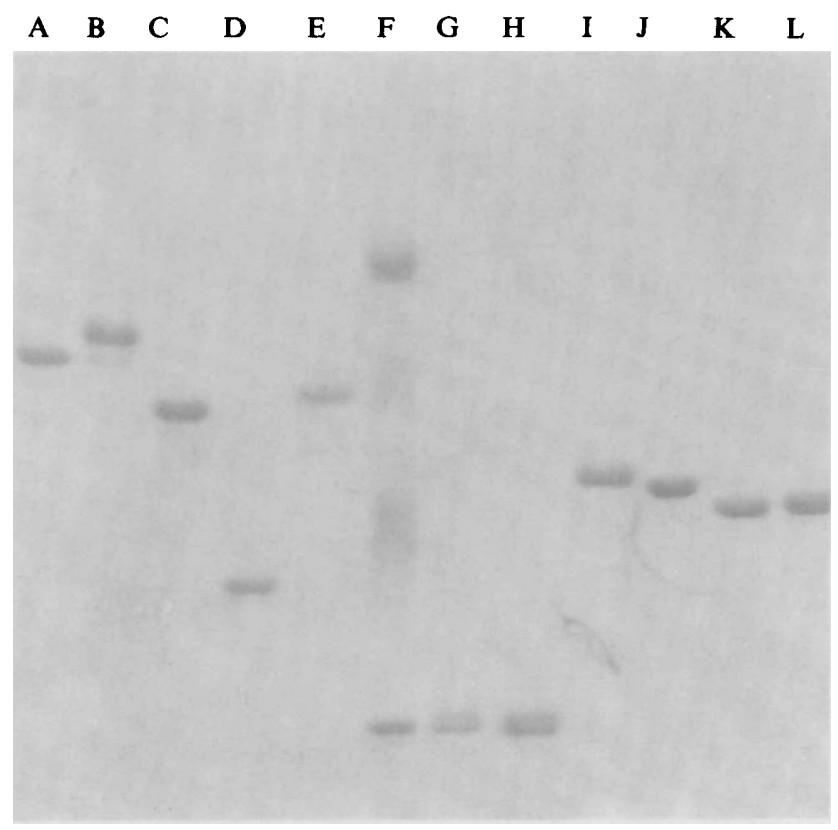

Fig. 2. SDS-PAGE of enterobacterial flagellin proteins. Pre-stained $M_{\mathrm{r}}$ markers (lane F) comprised (from top to bottom): phosphorylase B $\left(M_{\mathrm{r}} 97000\right)$; BSA (65000); ovalbumin (45000); and carbonic anhydrase ( 31 000). The samples were: Escherichia coli isolates EC51 (lane A), EC2 (B), EC8 (C), EC50 (D) and K12 (E); Enterobacter cloacae isolates $\mathrm{MC1} 7$ (G) and NJ4 (H); Serratia rubidea isolates $\mathrm{O} 13$ (I) and O10 (J); Salmonella arizonae $\mathrm{O8}(\mathrm{K})$; and Hafnia alvei W12 (L).

Table 3. ELISA of mAb 15D8 versus non-motile cells, motile cells and flagellar protein

\begin{tabular}{llccc}
\hline \hline & & \multicolumn{3}{c}{$A_{414}$} \\
\cline { 3 - 5 } \multicolumn{1}{c}{ Bacterium } & Strain & $\begin{array}{c}\text { Non- } \\
\text { motile* }\end{array}$ & Motile $\dagger$ & Flagella \\
\hline Escherichia coli & EC2 & 0.06 & $0 \cdot 82$ & $0 \cdot 75$ \\
Escherichia coli & EC4 & $0 \cdot 03$ & $0 \cdot 82$ & $0 \cdot 45$ \\
Escherichia coli & EC8 & $0 \cdot 05$ & $0 \cdot 25$ & $0 \cdot 71$ \\
Escherichia coli & EC10 & $0 \cdot 07$ & $0 \cdot 87$ & $1 \cdot 25$ \\
Enterobacter agglomerans & MC14 & $0 \cdot 08$ & $0 \cdot 70$ & ND \\
Enterobacter agglomerans & GBP7 & 0.05 & $2 \cdot 45$ & ND \\
Enterobacter cloacae & OH12 & $0 \cdot 09$ & $0 \cdot 87$ & ND \\
Pseudomonas aeruginosa & CA6 & NA & $0 \cdot 11$ & $0 \cdot 17$ \\
Pseudomonas aeruginosa & WS48 & NA & $0 \cdot 18$ & $0 \cdot 16$ \\
\hline \hline
\end{tabular}

ND, Not done.

NA, Not applicable (no non-motile isolates were found).

* Microscopic examination of sample wet mounts and the lack of motility on $\mathrm{BHI} / 0.4 \%$ agar plates confirmed these strains to be nonmotile.

† Motile cells for each strain were induced by three passages of nonmotile cells through U-tubes. Fresh preparations of whole bacteria were used to coat the ELISA plates.

Klebsiella and Pseudomonas species. These results are not surprising, since Klebsiella and Shigella species do not possess flagella.

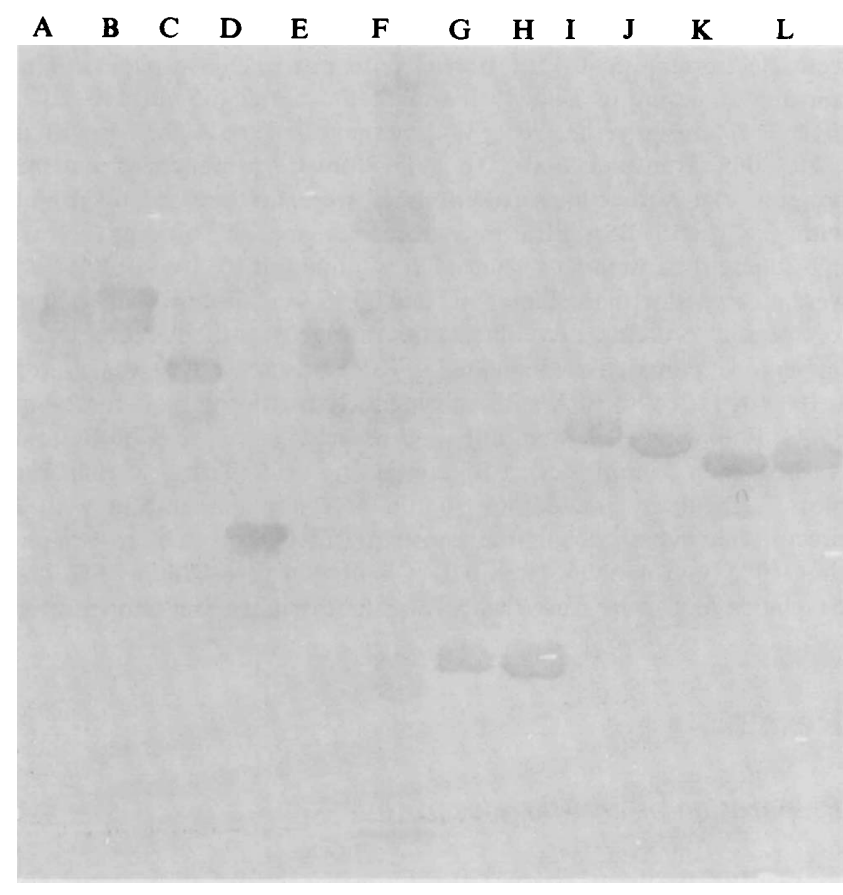

Fig. 3. Immunoblot of enterobacterial flagellin proteins using $\mathrm{mAb}$ 15D8. Samples and $M_{\mathrm{r}}$ markers are identical to those in Fig. 2.

\section{Induction of motility}

The absence of reactivity to $\mathrm{mAb} 15 \mathrm{D} 8$ in non-motile Shigella and Klebsiella strains further supports the specificity of the antibody for the bacterial flagella. The inability of 15D8 to react with all the isolates of a genus (Table 2) may be due to the absence of flagella. To test this hypothesis, several isolates which did not give a positive reaction by ELISA were microscopically examined for motile cells. If possible, motile cells were induced and partially purified flagella were prepared. Table 3 shows that for each isolate tested, antibody reactivity closely correlated with cell motility. In each case the antibody did not react with non-motile cells; however, of the organisms which could be induced to motility, good reactivity with the antibody was observed. Accordingly, flagellar proteins isolated from the same strains also reacted well with the antibody. No antibody reactivity was found either with motile cells or with purified flagellin from the Pseudomonas isolates examined, thereby supporting our assumption that the 15D8 epitope is present only on motile enterobacterial species.

\section{Heterogeneity of flagella size}

Flagella are known to be heterogeneous in size. Flagellin preparations from several enterobacterial species were fractionated by SDS-PAGE, blotted onto nitrocellulose 
paper, and probed with mAb 15D8 to determine whether its epitope was present only on some strains of a particular size. Fig. 2 shows the migration patterns of 11 enterobacterial flagellin preparations. Flagellin monomers from different isolates of Enterobacter (lanes $\mathrm{G}$ and $\mathrm{H} ; M_{\mathrm{r}} 28000$ ) and Serratia (lanes I and J; $M_{\mathrm{r}} 47-48000$ ) showed only slight variations in apparent $M_{\mathrm{r}}$ as compared to the Escherichia isolates (lanes A-E; $M_{\mathrm{r}} 36-$ 68000). The immunoblot showed that the flagellin proteins from all the isolates examined reacted strongly with the antibody (Fig. 3). The minor antibody-reactive bands, observed mostly in the $E$. coli samples (Fig. 3, lanes $\mathrm{A}-\mathrm{E}$ ) and as a doublet in the Enterobacter samples, are probably degradation products of flagellin. An immunoblot of a cell extract of Enterobacter showed only a single antibody reactive protein (Fig. 1, lane A2).

\section{Discussion}

SDS-PAGE analyses of flagellar proteins from $E$. coli $\mathrm{K} 12$ and six $E$. coli EC strains showed that only a single polypeptide was isolated from each strain but that the $M_{\mathrm{r}}$ of this protein varied greatly. The apparent $M_{\mathrm{r}}$ values of these flagellar proteins confirmed previously reported values for Serratia, E. coli and Pseudomonas (Kondoh \& Hotani, 1974; Allison et al., 1985; McDonough \& Smith, 1976). Significant variation in flagellin $M_{\mathrm{r}}$ has been observed only for E. coli and Salmonella species (Homma et al., 1987; Joys, 1988; Langman, 1972). The existence of evolutionary conserved and variable regions on the flagellin structural gene (hag) has been proposed by Iino (1977) and other investigators (Lawn, 1977; McDonough, 1965; McDonough \& Smith, 1976). Genetic and amino acid analyses have confirmed that the aminoand the carboxy-terminus of flagellin proteins from various genera appear to be highly conserved, whereas the sequences are more variable towards the central regions of flagellin (Joys, 1976, 1985; Kuwajima et al., 1986; Szekely \& Simon, 1983; Wei \& Joys, 1985). This information correlates with the recent findings that the carboxy-terminus of flagellin is essential for flagellar polymerization and excretion (Homma et al., 1987), and the variable flagellin immunogenicity reflects the central region of the gene (Joys, 1976, 1985; Kuwajima, 1988a). The clustering of essential bases at the terminus of the flagellar gene would allow for mutations within the central region without affecting flagella assembly and function. Kuwajima (1988b) used deletion analysis to confirm that 187 amino acid residues could be deleted from the central region of $E$. coli $\mathrm{K} 12$ flagellin without destroying flagella formation or functionality. Mutations within this central, variable region would account for the variations in $\mathbf{H}$-antigen serotypes within a genus (Joys,
1976; Yamaguchi et al., 1984). Variations in H-antigen types have previously been shown to be closely associated with flagellin morphology in $E$. coli (Kuwajima, $1988 a$; Lawn et al., 1977) and with variations in flagellin $M_{\mathrm{r}}$ in Pseudomonas aeruginosa (Allison et al., 1985) and Campylobacter (Harris et al., 1987). Insertions and deletions in this central region could also explain the heterogeneity in $E$. coli flagellar protein sizes observed in our study.

A flagella preparation from $E$. coli was used to produce a mAb, 15D8, which reacted with enterobacterial flagella. Previously, Ibrahim et al. $(1985 b, c)$ found that polyclonal sera produced against Salmonella flagellar protein cross-reacts with flagella from $E$. coli and other members of the Enterobacteriaceae. However, the flagellar protein had to be heat-denatured or in the unfolded-state in order to show serological reactivity with the antibody. This suggests that the epitope reported by Ibrahim et al. (1985c) is most likely an internal epitope that only becomes accessible to antibody under denaturing conditions. Similar results were obtained in the analysis of Campylobacter flagella, where the conserved or broadly cross-reactive epitopes were predominantly internal and only immunoreactive after denaturation (Harris et al., 1987; Logan \& Trust, 1986). The results of our studies suggest that the epitope for mAb 15D8 is probably surface exposed and linear, since antibody reactivity to enterobacterial flagella was obtained with either undenatured flagellar protein (ELISA) or with SDS-denatured antigen (immunoblots). One interesting exception however, was a flagella preparation of a laboratory strain of $E$. coli $\mathrm{K} 12$, which reacted with 15D8 only on immunoblots. It appears, therefore, that some denaturation of $\mathrm{K} 12$ flagellin is essential to expose this epitope for antibody reactivity. The broad reactivity of 15D8 also suggests that the antibody might be useful for the detection of coliforms isolated from environmental or clinical specimens.

The analysis of flagellar antigens with mAb 15D8 under both denaturing and non-denaturing conditions shows that the epitope to this antibody is conserved in the Enterobacteriaceae. All $E$. coli flagellin proteins tested, which varied greatly in $M_{\mathrm{r}}$, also reacted with the antibody. These results would suggest that the epitope for mAb 15D8 is most likely located on the conserved region of the flagellin protein. Additional supporting evidence on the conserved nature of this epitope was obtained when cell extracts of Salmonella were examined. The genetic sequences for phase I and II flagellin in Salmonella are homologous but not identical, hence the products are antigenically distinct (Joys, 1988; McDonough, 1965). Immunoblots (unpublished data) of $S$. typhimurium cell extracts showed that $\mathrm{mAb}$ 15D8 reacted with two proteins (doublet) with the apparent $M_{\mathrm{r}}$ values 
of the phase I and II flagellin types. In addition, the IgA antibody MOPC467, which also reacts with both phase types of Salmonella flagella (Smith \& Jones, 1983), reacted with the same protein doublet as 15D8 on immunoblots of $S$. typhimurium extracts.

The highly conserved nature of this epitope across $M_{\mathrm{r}}$, phase variation and generic barriers would suggest that it may be vital to flagella structure and function. Mapping the epitope using site-directed mutagenesis should further define the role and the location of the epitope. $\mathrm{mAb}$ 15D8 should be useful in studies of flagellar transport, assembly and polymerization as well as in genetic regulation of flagella morphogenesis.

The authors thank Drs H. Ochman, R. K. Selander, P. A. Hartman and $B$. Swaminathan for providing cultures used in this study, and Drs P. Matsumura, W. E. Hill and S. A. Minnich for helpful discussions and critical review of this manuscript.

\section{References}

Ada, G. L., Nossal, G. J. V., Pye, J. \& ABbot, A. (1964). Antigens in Immunity. I. Preparation and properties of flagellar antigens from Salmonella adelaide. Journal of Experimental Biology and Medical Sciences 42, 267-282.

Allison, J. S., Dawson, M., Drake, D. \& Montie, T. C. (1985). Electrophoretic separation and molecular weight characterization of Pseudomonas aeruginosa $\mathrm{H}$-antigen flagellins. Infection and Immunity 49, 770-774.

Harris, L. A., Logan, S. M., Guerry, P. \& Trust, T. J. (1987). Antigenic variation of Campylobacter flagella. Journal of Bacteriology 169, 5066-5071.

Homma, M., Fujita, H., Yamaguchi, S. \& IINo, T. (1987). Regions of Salmonella typhimurium flagellin essential for its polymerization and excretion. Journal of Bacteriology 169, 291-296.

Ibrahim, G. F., FleEt, G. H., LyONS, M. J. \& WalKer, R. A. (1985a) Method for the isolation of highly purified Salmonella flagellins. Journal of Clinical Microbiology 22, 1040-1044.

IBRAHIM, G. F., FleEt, G. H., LyONS, M. J. \& WALKeR, R. A. (1985b) Immunological relationship between Salmonella flagella and their potential application for salmonellae detection by immunoassay. Medical Microbiology and Immunology 174, 87-99.

Ibrahim, G. F., Fleet, G. H., Lyons, M. J. \& Walker, R. A. (1985c). Immunological relationship between Salmonella flagellin and between these and flagellin from other species of Enterobacteriaceae. Medical Microbiology and Immunology 174, 101-113.

IINO, T. (1977). Genetics of structure and function of bacterial flagella. Annual Review of Genetics 11, 161-182.

JoYs, T. M. (1976). Identification of an antibody binding site in the phase-1 flagellar protein of Salmonella typhimurium. Microbios 15 , 221-228.
Joys, T. M. (1985). The covalent structure of the phase-1 flagellar filament protein of Salmonella typhimurium and its comparison with other flagellins. Journal of Biological Chemistry 260, 15758-15761.

JoYs, T. M. (1988). The flagellar filament protein. Canadian Journal of Microbiology 34, 452-458.

KONDOH, H. \& HOTANI, H. (1974). Flagellin from Escherichia coli K 12: polymerization and molecular weight in comparison with Salmonella flagellins. Biochimica et Biophysica Acta 336, 117-139.

KUWAJIMA, G. (1988a). Flagellin domain that affects $\mathrm{H}$ antigenicity of Escherichia coli K-12. Journal of Bacteriology 170, 485-488.

KuWAJMa, G. (1988b). Construction of a minimum-size functional flagellin of Escherichia coli. Journal of Bacteriology 170, 3305-3309.

Kuwajima, G., Asaka, J., Fujiwara, T., Node, K. \& Kondoh, E. (1986). Nucleotide sequence of the hag gene encoding flagellins of Escherichia coli. Journal of Bacteriology 168, 1479-1483.

LAEMMLI, U. K. (1970). Cleavage of structural proteins during the assembly of the head of bacteriophage T4. Nature, London 227, 115120.

LANGMAN, R. E. (1972). The occurrence of antigenic determinants common to flagella of different Salmonella strains. European Journal of Immunology 2, 582-586.

LAwn, A. M. (1977). Comparison of the tlagellins from different flagellar monotypes of Escherichia coli. Journal of General Microbiology 101, 121-130.

Lawn, A. M., Orskov, I. \& Orskov, F. (1977). Morphological distinction between different $\mathrm{H}$ serotypes of Escherichia coli. Journal of General Microbiology 101, 111-119.

LoGAN, S. M. \& TRUST, T. J. (1986). Location of epitopes on Campylobacter jejuni flagella. Journal of Bacteriology 168, 739-745.

MCDonough, M. W. (1965). Amino acid composition of antigenically distinct Salmonella flagellar proteins. Journal of Molecular Biology 12 , 342-355.

MCDonough, M. W. \& SMith, S. E. (1976). Molecular weight variation among bacterial flagellins. Microbios 16, 49-53.

MACNAB, R. M. (1987). Flagella. In Escherichia coli and Salmonella typhimurium: Cellular and Molecular Biology, pp. 70-83. Edited by F. C. Neidhardt. Washington, DC: American Society for Microbiology.

OChman, H. \& Selander, R. K. (1984). Standard reference strains of Escherichia coli from natural populations. Journal of Bacteriology 157 , 690-693.

Robison, B. J., Pretzman, C. I. \& Mattingly, J. A. (1983). Enzyme immunoassay in which a myeloma protein is used for detection of salmonellae. Applied and Environmental Microbiology 45, 1816-1821.

SMith, A. M. \& Jones, C. (1983). Use of murine myeloma M467 for detecting Salmonella spp. in milk. Applied and Environmental Microbiology 46, 826-831.

SMith, A. M. \& PotTer, M. (1976). A BALB/c mouse IgA myeloma protein that binds Salmonella flagellar protein. Journal of Immunology 114, 1847-1850.

Sugasawara, R. J., Prato, C. \& Sippel, J. E. (1983). Monoclonal antibodies against Neisseria meningitidis lipopolysaccharide. Infection and Immunity 42, 863-868.

SZEKeLY, E. \& Simon, M. (1983). DNA sequences adjacent to flagellar genes and evolution of flagellar-phase variation. Journal of Bacteriology 155, 74-81.

WEI, L. \& JOYs, T. M. (1985). Covalent structure of three phase-1 flagellar filament proteins of Salmonella. Journal of Molecular Biology 186, 791-803.

Yamaguchi, S., Fumita, H., Sugata, K., Taira, T. \& IIno, T. (1984). Genetic analysis of $\mathrm{H} 2$, the structural gene for phase-2 flagellin in Salmonella. Journal of Gene Microbiology 130, 255-265. 